\title{
The Application of Waqf and Endowment Fund Based on the Principles in the Sharia Maqashid Pillar Society
}

\author{
Akhmad Kusuma Wardhana \\ Department of Islamic Economy, Universitas Airlangga, Indonesia \\ email: akhmadkusumaw@gmail.com,+6285736625652
}

\begin{abstract}
Islam regulates economic life for the benefit of all. Waqf can be a solution in creating mutual benefit in society. This study aims to analyze the comparison between the practice of waqf for both Muslims and non-Muslims. This study uses qualitative methods. Samples in this study are the Islamic Hospital of endowments and the Gates Foundation. Data were analyzed using descriptiveanalytical methods. The results show that the Gates Foundation and UNISMA use funds from their business management to distribute to the public. If UNISMA distributes waqf funds for business development and to achieve goodness, the gates foundation is entirely donated to the public. The difference in the company's financial scale is this division.
\end{abstract}

Keywords: Gates Foundation, public welfare, UNISMA, waqf.

\begin{abstract}
ABSTRAK
Islam mengatur kehidupan ekonomi untuk kepentingan bersama. Wakaf dapat menjadi solusi dalam menciptakan saling menguntungkan dalam masyarakat. Penelitian ini bertujuan untuk menganalisis perbandingan antara praktik wakaf baik bagi muslim maupun nonmuslim. Penelitian ini menggunakan metode kualitatif. Sampel dalam penelitian ini adalah Rumah Sakit Islam wakaf dan Gates Foundation. Analisis data menggunakan metode deskriptif-analitis. Hasil penelitian menunjukkan bahwa Gates Foundation dan UNISMA menggunakan dana dari pengelolaan usahanya untuk disalurkan kepada masyarakat. Jika UNISMA menyalurkan dana wakaf untuk pengembangan usaha dan mencapai kebaikan, maka yayasan gates seluruhnya disumbangkan untuk masyarakat. Perbedaan skala keuangan perusahaan adalah divisi ini.
\end{abstract}

Kata kunci: Gates Foundation, kesejahteraan masyarakat, UNISMA, wakaf. 


\section{INTRODUCTION}

Islam is a universal religion where Islam does not see the period, time, or place (Rokhmiyati 2018). Islam is for all humankind in the world. Aspects regulated in Islam cover all aspects of life in the world (Muslim and Widayatsari, 2019). It also includes the economic aspect, which is one of Muamalah, so that the affairs of muamalah and worship must be carried out as well as possible (Nienhaus, 2010).

Economics is a science that regulates the way humans make ends meet. Islam views that the purpose of humans to fulfill their needs is to create benefit by achieving Maqashid Syariah (Kamelia 2018). Maslahat means something that is good and can be understood by reason that the purpose of Islamic law is set for the benefit of humankind (Sahlan, Abu-Hussin, and Hehsan 2019). According to Al-Ghazali, maslahah means getting all the benefits and getting rid of the harm (Gani 2020). Therefore, as stated in the QS, the holy goal in implementing everything must be oriented to maslahah by doing good and avoiding evil. An-Nahl verse 90 follows:

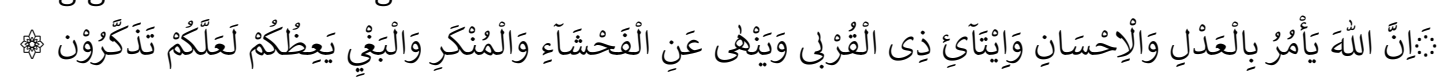

Meaning: Verily Allah commands (you) to do justice and do good, to give help to relatives, and He forbids (to do) vile deeds, evil, and enmity. He teaches you so that you can take lessons.

Humans as social creatures cannot live without interacting with other humans. That is why there is an economic activity where humans fulfill their needs by utilizing the results made by others, such as when consuming rice made from rice. The rice is grown, cared for, and harvested by a farmer (Zakiy, Ridwan, and Supriyanto 2021). That is the function of a rice producer. Islamic economics views scarcity as a fundamental economic problem. With the deficits in fulfilling people's basic needs, individuals are obliged to help others with difficulty meeting their basic needs (Barata, 2019).

However, Islam does not require competition due to the scarcity of meeting needs (Utama and Dewi, 2020). In contrast to the principles of capitalist economics, which emphasize competition between individuals in controlling resources, Islamic economics puts forward the principle of mutual help between human beings (Rizki et al. 2017). The nature of helping in Islam is based on the principle in the Qur'an, where the property is a deposit from Allah SWT, not ours completely. It encourages Islamic economics to manage funds to channel them to those in need, as in ZISWAF (Zakiy et al. 2021).

Waqaf or endowment fund is a form of management of donation funds, both from agencies and the community to be used for the benefit of the community(Elnazer et al. 2021). Waqf can be in the form of fixed assets such as buildings or movable assets such as companies (Sapuan et al. 2018). The most commonly used waqf is for places of worship and public places. Public places commonly used to rotate waqf funds are usually in the form of SMEs or business entities, where profit sharing is used to finance businesses from other waqf funds or just donated directly to those in need (Abubakar, 2019).

Waqf was categorized as social fund/tabarru, where the purpose was solely for the prosperity of all. Nazir, who manages the waqf in the form of funds or items, could use it to create a potential business so that nazhir could take part in the profit and manage the rest of the profit to expand the business. The more business expanded using waqf funding, and the more fund could be allocated for waqf for profit gained. Based on that background, this study aims to analyze waqf 
implementation in institutions owned by Muslims and sectors owned by non-Muslims known as endowment funds.

Islam has a system that regulates the economic activities of its people. The Islamic economic system is a collection of rules, values, and standards of behavior that regulate economic life and establish production relations in Islamic society (Gani 2020). These rules and standards are based on the Islamic order as recognized in the Qur'an and Sunnah and the rules of jurisprudence developed over the last 1400 years by thousands of jurists, such as ijma and qiyas (Ibrahim and Alam 2018).

The Islamic economic system responds to changing circumstances and the lives of Muslims developing around the world to adapt to the needs of the times (Harjanto et al. 2019). Islamic economics always accommodates the latest economic rules and the least criticized economic definitions and synergizes them with Islamic rules (Nor, Ibrahim, and Daud 2020). Although the capitalist economic system has already been used in economic activities, the Islamic economic system does not force its people to abandon the old economic system entirely. Muslims only need to filter economic practices that follow Islamic law without completely abandoning the old system (Yazid et al. 2020).

Choudry in Maulidizen (2019) divides economic activity in terms of faith and within the framework of sharia. The frame of faith requires every human being to straighten his intentions in carrying out economic activities in worshiping Allah SWT with sincerity and patience. Impatience brings evil because impatience drives people to greed and deprivation of the rights of others (Maulidizen 2019).

Maqashid sharia is the goal set by Islamic law to create benefit for society. The purpose of maqashid sharia is to obtain success or falah in this world and the hereafter (Zakiy et al. 2021). The completeness of maqashid sharia includes the aims and objectives that must be followed in all activities, including economic activities such as finance, banking, takaful, and social activities. Islam has creed laws that regulate religious beliefs and procedures and has a comprehensive set of rules and norms for human behavior (Abadi and Abbas 2019).

Maqashid sharia has five pillars, which must be implemented sequentially. The five pillars are protection or hifdz for religion, then continued on the soul, then on offspring, then on intellectuals, and finally on property. The arrangement of these five pillars should not be reversed to create benefits for the community (Dargahi, Nasrollahzaedeh, and Rahmani 2017).

In Islamic/sharia economics itself, maqashid sharia is the main guideline for equitable distribution of economic results and reducing social inequality. Islamic economics has a ZISWAF practice to reduce economic inequality, where the wealthy are obliged to give rights to the property of the poor (Masyita, Tasrif, and Telaga 2005). Abdullah, in his study, suggests that maqashid sharia itself is the basis for planning sustainable development goals (SDGs) to realize prosperity and peace throughout the world so that no rights of every community in the world are taken away by a few people. The central vision of the SDGs is similar to maqashid sharia to maintain the benefit of the community on an ongoing basis (W. Abdullah, 2018). 


\section{METHOD}

This study used a case study approach with a literature review in collecting data. The data used is only secondary as the research sample. The sample in this study is the Islamic Hospital as an object provided by waqf and the Gates Foundation (Seprillina et al. 2020). he sample was analyzed using the maqashid sharia theory using five pillars to explain the closeness between endowment fund and waqf practices and Islamic economics (Nienhaus, 2010).

This study compared waqf funds managed by two Islamic Hospitals in Indonesia and some institutions managed by Gates Foundation using endowment funds. The maqashid sharia pillars consist of five: protection of religion, life, mind, legacy, and property. The maqashid sharia will be used as a base theory to explain waqf management by Islamic hospitals and endowment funds by Gates Foundation, whether they followed one or two principles or violated them. This study also observed which maqashid principle was used most frequently reflected in the management of funds by samples (Rusydiana and Firmansyah, 2018).

\section{RESULTS AND DISCUSSION}

\subsection{Empowerment of Hospital Waqf in Indonesia According to Maqashid}

The waqf empowerment model for hospitals can be applied by utilizing waqf assets to assist the development of health services through the provision of public facilities in the health sector, such as the construction of hospitals, construction of health schools, and development of medical sciences, as well as industrial development in the field of medicine and chemistry (Herianingrum et al. 2020). The empowerment of waqf has been implemented in Egypt. They manage hospitals productively by setting management structures, providing specialist doctors, and setting rates (McChesney, 2014).

In Indonesia, several hospitals are funded from productive waqf, and their management needs to be improved. The production waqf has financed several hospital constructions, such as the Sultan Agung Islamic Hospital (RSI SA) (Kasdi 2016). By getting productive waqf empowerment funds, you can get adequate results to reach the break-even point (BEP) Within a certain period (Rofai, Burhan, and Multifiah, 2016).

After reaching the break event point and getting a significant profit, it is also expected to provide cross-space health benefits and other benefits. Thus, the health facilities with good services are not only felt by certain groups but can be felt by all people (Yulianingtyas, Wigati, and Suparwati, 2016). Following the letter At Taubah, the obligation to issue zakat or alms to purify wealth. In this case, RSI SA applies the principle of purifying property through empowering free health services to people who cannot afford it (Widiastuti 2017). the principle of purifying property is in line with the verse of the Qur'an, which reads: Take zakat from some of their wealth to cleanse, purify them, and pray for them. Verily, your prayer (grows) peace of mind for them. And Allah is AllHearing, All-Knowing. (Surat At-Taubah: 103).

Another example of the use of waqf in Indonesia is the construction of a VIP classroom at the Islamic Hospital in Malang, East Java. Malang Islamic Hospital is under the management of the Malang Islamic University Foundation (UNISMA) while occupying land owned by Al-Ma'arif and Madrasah Aliyah Negeri 1 Malang, covering an area of $2 \mathrm{H}$. Malang Islamic Hospital received productive waqf empowerment of around 2 billion Rupiah (Yulianingtyas et al. 2016). Malang 
Islamic Hospital manages $20 \%$ of profits from hospital management for mauquf Alaih, such as mosque cleaners, mosque imams, inviting clerics or religious leaders at Islamic study events (Budiman, 2016).

In the perspective of maqashid sharia, UNISMA applies the principle of protecting religion through the empowerment of mosques. In addition, UNISMA also prioritizes the principle of protection of religion/hifdz al-din above the protection of property, namely enjoying the benefits of economic activity, namely financing the needs of the mosque from $20 \%$ of hospital cash flow. Hifdz Ad-Din is needed so that the symbols of Islam in society can remain sustainable (Zakiy et al. 2021). "In their wealth, there is a right for the poor who ask and the poor who do not get a share" (Surah Adz-Dzariyat: 19).

The hospital foundation also manages schools where waqf money is also used to help the needs of economically disadvantaged diniyah teachers (Haliza 2020). In addition to this management, the Malang Islamic Hospital also uses waqf funds to provide free health services to underprivileged patients. Not all levels of society can afford to pay for hospital treatment. In addition, waqf funds are also used for cleft lip surgery for the public (Sari 2020).

The financing of health services is also included in one of the pillars of maqashid, namely protecting the soul/hifdzu nafs, sick people who need emergency assistance but are constrained by costs. They have a safe life with this financing program by following the fifth principle of Pancasila, social justice for all Indonesian people. People from the lower classes must be given the right to receive health care the same as the middle and upper classes. Both the fifth principle and maqashid sharia are pillars of the Indonesian nation, must be obeyed, both as citizens and Muslims who live in the homeland (Rahman et al. 2017).

UNISMA also utilizes waqf funds to build several minimarkets in managing waqf funds. About $20 \%$ of the profits from the business management will be donated directly to the mauquf alaih. At the same time, 70\% is used to develop existing business units (Haliza 2020). The contract used by UNISMA is mudharabah, where UNISMA is the owner of the capital and the minimarket as the capital manager shares the cash flow (Choudhury and Malik 2016). UNISMA's share (ujrah) will be used to subsidize other waqf projects or be handed over to the mauquf alaih (Nur 2018). This principle follows the maqashid sharia, where safeguarding property is preceded by protecting the community's life, or hifdz, and nafs through the management of waqf funds through business units (Ismail 2018).

The remaining $10 \%$ of profit is given to the nadzir as the manager of the waqf fund (Seprillina et al. 2020). In total, there are 7 minimarkets managed by the foundation, namely Al Khaibar, Rois Dahlan, Go Fish, Sabilillah, Al Haromain, Bantaran, and Jl Bondowoso minimarkets. The more variety of business fields, the smaller the capital owner's risk through business diversification (Nienhaus 2010). Risk diversification is following sharia economic principles, where economic transactions are not charged to only one party. This model is to create the benefit of each other so that no party feels disadvantaged while the other party benefits (Rahman et al. 2017).

In the waqf fund management strategy by UNISMA, diversification of business types is one way to reduce risk. Diversification allows more variety and choices for products and services that consumers can utilize. If applied to the right target market, diversification provides a tremendous boost to a company's brand image and profitability (Nur 2018). 
Diversification can be used as a defense. By diversifying products or services, companies can protect themselves from competing companies. In the case of dairy cattle in a slow-growing market, diversification allows companies to take advantage of surplus cash flows to finance which products have more market prospects (Villa, Adenso-Díaz, and Lozano 2019). When a company reaches a certain point in its evolution, founders, investors, and executives often plan and implement growth strategies, such as diversification (Sun, Peng, and Tan, 2017).

Diversification can also be classified as property protection as one of the pillars of maqashid. Business diversification as a way to utilize waqf funds by UNISMA also includes the maqashid pillar. In addition, risk diversification can also maintain the trust of waqf donors and investors who help in the success of the business line managed by UNISMA (Haliza, 2020).

According to a study by Villa et al., diversification of products and services can increase a company's competitiveness. Focusing on one or two customers can limit a company's thinking and growth prospects (Villa et al. 2019). In addition, it can happen where one big customer of a company may not be on the cutting edge of market needs because the products offered are not relevant to what they want. Through diversification, it can meet the various scope of customer needs. "From Abu Hurairah RA, he said: "The Messenger of Allah (PBUH) forbade buying and selling by throwing stones and also forbids buying and selling that contains elements of deception." (HR. Muslim).

The above hadith describes the prohibition of trading that contains high risk. Especially in the management of UNISMA waqf funds, risk management through diversification is important to maintain the trust of capital owners (Nur 2018). It is not enough to rely on religion in economic management. Reliable management and business strategies are needed to survive the fierce competition and demands of the times. It is stated in the verse of the Qur'an. "O you who believe, do not betray Allah and the Messenger (Muhammad) and (also) do not betray the mandates entrusted to you, while you know (Surah Al Anfaal: 27).

In the principles of Islamic economics, all the activities must be avoided from significant risks to create ambiguity. This risk can result in large financial losses, injuring business units (Maulidizen 2019). By sharing risk, economic activity can be avoided from the practice of gharar so that no party benefits from the suffering of the other party. The principle of justice in the economy is a pillar that is upheld by maqashid sharia, namely the safety of property/hifdz Al-Maal (Zakiy et al. 2021). "And do not let some of you eat the wealth of the other part of you falsely and (do not) bring (the affair) the property to the judge so that you can eat part of the property of others with (the way of doing) sin, even though you know" (Surah al-Baqarah: 188).

\subsection{Implementation of Endowment Fund by Gates Foundation According to Maqashid Sharia'}

No one is not familiar with the figure of Bill Gates. The man who founded the giant company Microsoft is one of the wealthiest people in the world. With a total net worth of \$129 billion, Bill Gates owns property and wealth (Kovacs 2010). But the super majestic wealth does not make Gates forget about social care. He and his wife, Melinda Gates, founded the Gates Foundation to help the oppressed, especially the poor (Kovacs 2010). But the super majestic wealth does not make Gates forget about social care. He and his wife, Melinda Gates, founded the Gates Foundation to help the oppressed, especially the poor (Garcia and Wanner 2017). 
Bill \& Melinda believes that everyone has equal rights in life. Through the Gates Foundation, they work to help everyone live healthy and productive lives. The Gates Foundation helps people in developing countries whose focus is on improving public health and escaping hunger and extreme poverty through education. In sharia economic principles, every property owned by humans has the rights of the poor. It is a way to support income distribution in society without inequality between the rich and the poor (Chueva et al. 2016).

In the United States itself, like their hometown, the Gates Foundation strives for children who fall into the abyss of poverty to have access to education. The Gates Foundation is headquartered in Seattle, Washington DC. The foundation is led by CEO Mark Suzman, under Bill and Melinda Gates and Warren Buffett, the world's third-richest investor (Au and Lubienski 2016).

The Gates Foundation was founded in 2000 through the merger of two Gates foundations. Their main priority is handling global health, education, and libraries. In 2006, the Gates Foundation divided its divisions into a Global Development, Global Health, and Special Initiatives division (Walker 2016).

Table 1

Comparision between Waqf by Islamic institutions and Endowment fund by Gates foundation

\begin{tabular}{|l|l|l|}
\hline & $\begin{array}{l}\text { Islamic Hospital UNISMA \& } \\
\text { Sultan Agung Islamic Hospital }\end{array}$ & Gates Foundation \\
\hline Challenges & $\begin{array}{l}\text { 1. The limited source of funding } \\
\text { 2. Scope only in local } \\
\text { 3. limited for Islamic religious activities }\end{array}$ & $\begin{array}{l}\text { A source was uncertain from } \\
\text { halal or haram economic } \\
\text { activities. }\end{array}$ \\
\hline Opportunities & $\begin{array}{l}\text { It could be used for economic activities } \\
\text { Srength }\end{array}$ & $\begin{array}{l}\text { Funding could be expanded } \\
\text { greatly every year, based on } \\
\text { Microsoft's profit }\end{array}$ \\
& $\begin{array}{l}\text { - Funding guaranteed from halal source } \\
\text { - The diversification of products for the } \\
\text { fund management }\end{array}$ & $\begin{array}{l}\text { - The huge scale of funding } \\
\text { - International scale } \\
\text { distribution } \\
\text { - Not limited to Islamic } \\
\text { religious activities }\end{array}$ \\
& & $\begin{array}{l}\text { Microsoft was hard to be } \\
\text { collapsed or near } \\
\text { bankruptcy }\end{array}$ \\
\hline
\end{tabular}

The Global Development Division in GATES foundation handles funding for extreme poverty and hunger in developing and conflict-ridden countries. The Gates Foundation forges strategic partnerships to channel targeted grants for agricultural development programs (Black et al. 2009). The program is considered to help increase opportunities for farmers in developing countries to remain productive (Iman and Mohammad, 2017).

In addition, the Gates Foundation also finances a series of research programs on increasing the production of rice and flour enriched with micronutrients. The program also seeks to improve financial services for the poor by funding strategic projects so that the profits can be used as capital loans and insurance for financial education in developing countries (Au and Lubienski, 2016).

The Global Development Division is also committed to expanding the global library program. Global libraries were initiated to create modern libraries in developing countries by synergizing with 
supporting organizations to increase access to information technology. The Gates Foundation recognizes that without the support of good library facilities, the pace of a country's education can be hampered. Therefore literacy is the key to accelerating the education growth program of developing countries (Ruslang, Kara, and Wahab, 2020).

In helping the growth of education, the Gates Foundation has implemented the pillar of maqashid, namely hifdz Al-Aql, or protection of reason. Education is the most essential weapon to fight ignorance so that the welfare of the people in a country can be achieved (Walker 2016). In the modern era, a nation's competitiveness must be focused on building economic growth, where competitiveness through the quality of human resources (HR) can create various innovations and the latest breakthroughs that can make a major contribution to the country's economy. Of course, to increase competitiveness, the quality of education must also be improved (M. Abdullah 2018). he Prophet in Hadith also said: "Whoever wants the happiness of the world, then seek knowledge and whoever wants the happiness of the hereafter, seek knowledge and whoever wants both, seek knowledge.

The above hadith shows that humans are always learning to get happiness not only in this world but also in the hereafter. Following its mission to improve literacy and the quality of education globally, the Gates Foundation provides educational facilities in libraries to developing countries to reduce illiteracy rates (Fendler 2018). Libraries are important as a place to gain knowledge other than at school and a place where various literature and books are stored. The verse of the Qur'an also emphasizes the importance of seeking knowledge. "Allah will exalt those of you who believe and those of you who know by several degrees." (Surat al-Mujdah 58:11).

The Global Special Initiatives Program provides grants to organizations researching issues of concern to the developing world, including water, sanitation, and hygiene. These issues are crucial, especially during the current COVID-19 pandemic (Sobanjo-ter Meulen et al. 2020), where sanitation and hygiene are the keys to controlling the spread of the pandemic. In addition, the Global Health division of the Gates Foundation contributes to addressing the high rates of mortality and morbidity from preventable diseases in developing countries (Chueva et al. 2016). This rate is related to the nutritional level of pregnant women and babies, prevention of polio, vaccine administration, emergency response, and the health of mothers and their newborns and children (Kashif, Menoncin, and Owadally 2019).

The global health division also focuses on endemic diseases, diarrhea, HIV/AIDS, malaria, neglected tropical diseases, pneumonia, and tuberculosis. The Gates Foundation is funding some projects to improve access to vaccines and existing treatments for common diseases (Black et al. 2009). The Gates foundation argues that the widespread disease and death in developing countries is the biggest injustice in health between developed and developing countries (Walker 2016). This case is because widespread epidemics in developing countries do not receive adequate attention and funding, so that many fatalities are inevitable (Khan 2001). According to the maqashid sharia principle, life protection depends not only on medical services but also on how to maintain public health sustainably. One of them is the availability of adequate food, clean water and air, and good sanitation (Musa, Harjanto, and Heni 2015).

The Global Health Division also supports projects that advance health research and technology in developing countries. The Gates Foundation supports the development of affordable medical 
devices for small communities and accurate in their use. The Gates Foundation also invests in vaccine development programs to prevent infectious diseases. It follows the principle of maqashid sharia, namely protecting the soul, where protecting the safety of one's soul and society is a human obligation as a caliph on earth (Hudaefi and Heryani 2019).

The division's major challenge is funding potential scientific breakthroughs to prevent, treat, and cure disease in developing countries (Kovacs 2010). In addition to disease-specific and specialty initiatives, the foundation has a Global Policy \& Advocacy division. This division builds strategic relationships with the government and public and private sectors to increase public awareness of public health issues. It also includes addressing global health advocacy efforts, particularly tobacco control, and global health interventions at the local and regional community level (Garcia and Wanner, 2017).

Interventions on commodities that only bring harm also include the implementation of maqashid sharia (Lesmana and Haron 2019). In this case, the Gates Foundation wants to break the chain of empowerment of the tobacco industry. Tobacco is one of the causes of many respiratory diseases that are detrimental to health and drain the country's foreign exchange through health insurance for treatment due to smoking (Siddiqui, Gorard, and See, 2016).

In this case, the intervention has protected the lives and property, namely Hifdz An-Nafs and Hifdz Al-Maal. Even though non-Muslims religiously found the Gates foundation, it does not mean that they lack social sensitivity and empathy for global problems. Through the endowment fund, the Gates Foundation wants to raise awareness about the dangers of the tobacco industry, especially for the health and economy of the country (M. Abdullah, 2018).

\section{CONCLUSION}

The Islamic economic system is a collection of rules, values, and standards of behavior that regulate economic life and establish production relations in Islamic society. Tabarru 'is a form of voluntary giving to others without expecting a reward or benefit from the giving process. In Islam itself, we are taught to help each other without expecting anything in return (sincere).

Even though the Gates Foundation is not a Muslim, it applies the principle of tabarru by managing its assets for multinational social purposes. Likewise, the UNISMA waqf principle manages waqf funds so that the medical interests of the community can utilize them. UNISMA diversifies its business entities so that the risk of loss received is more negligible. The funds channeled to the mauquf alaih or the one eligible to get charity can be even more fantastic.

\section{REFERENCES}

Abadi, Mustafa Kadhmi, and Drgham Aliawi Abbas. (2019). Underdevelopment and Development In the Islamic Economy. Al Kut Journal of Economic and Administrative Sciences 11(33):154-65.

Abdullah, Mohammad. (2018). Waqf, Sustainable Development Goals (SDGs) and Maqasid AlShariah. International Journal of Social Economics.

Abdullah, Wakit. (2018). Local Knowledge and Wisdom in the Javanese Salvation of Women Pregnancy 'Mitoni': An Etholinguistic Perspective. in Fourth Prasasti International Seminar on Linguistics (Prasasti 2018). Atlantis Press. 
Abubakar, Mustapha. (2019). Waqf Philanthropy and Orphans' Socio-Economic Development in Northern Nigeria Based on Maqasid Al Shariah Principles. Pp. 31-42 in Revitalization of Waqf for Socio-Economic Development, Volume I. Springer.

Au, Wayne, and Christopher Lubienski. (2016). The Role of the Gates Foundation and the Philanthropic Sector in Shaping the Emerging Education Market. World Yearbook of Education 27-43.

Barata, Amrin. (2019). "Strengthening National Economic Growth and Equitable Income through Sharia Digital Economy in Indonesia. Journal of Islamic Monetary Economics and Finance 5(1):145-68.

Black, Robert E., Maharaj K. Bhan, Igor Rudan, and Cesar G. Victora. (2009). Accelerating the Health Impact of the Gates Foundation.

Budiman, Achmad Arief. (2016). Partisipasi Stakeholder Dalam Perwakafan (Studi Kasus Di Rumah Sakit Roemani, Yayasan Badan Wakaf Sultan Agung, Dan Masjid Agung Semarang). Al-Ahkam 26(1):1-28.

Choudhury, Masudul Alam, and Uzir Abdul Malik. (2016). The Foundations of Islamic Political Economy. Springer.

Chueva, Tatiana I., Gulsina M. Niyazova, Andrey V Metsler, Dmitry V Shkurkin, Gulmariam H. Aznabaeva, and Leonid I. Kim. (2016). "Approaches to the Development of Endowment Funds in Russia as an Instrument of Mixed Financing of the Social Sphere." International Review of Management and Marketing 6(1S).

Dargahi, H., A. K. Nasrollahzaedeh, and H. Rahmani. (2017). An Investigation of Relationship between Spiritual Leadership Style with Organizational Commitment among Tehran University of Medical Sciences Staffs. International Journal of Asian Social Science 7(3):234-41.

Elnazer, Ahmed A., El-Montaser M. Seleem, Salah A. M. Zeid, Ismail S. A. Ismail, Hossam A. Bahlol, and Salman A. Salman. (2021). Hydrochemical Evaluation of the Quaternary Aquifer and Its Suitability for Different Purposes at South Al Waqf City, Qena, Upper Egypt. Groundwater for Sustainable Development 12:100517.

Fendler, Lynn. (2018). The Gates Foundation MET Research Project as a Case of Philanthrocapitalism. Pp. 239-59 in Educational research: Ethics, social justice, and funding dynamics. Springer.

Gani, Ibrahim Musa. (2020). Interest (Riba) and Its Consequence on the Economy. Journal of Islamic $5(30): 13-22$.

Garcia, Alicea Skye, and Thomas Wanner. (2017). Gender Inequality and Food Security: Lessons from the Gender-Responsive Work of the International Food Policy Research Institute and the Bill and Melinda Gates Foundation. Food Security 9(5):1091-1103.

Haliza, Siti Nur. (2020). Analisis Kebijakan Perlakuan Akuntansi Wakaf Produktif Minimarket AlKhaibar III Unisma Berdasarkan PSAK 112.

Harjanto, J. T., E. Prasetyo, S. I. Santoso, and E. Rianto. (2019). Performance of Islamic Boarding Schools in Developing the Beef Cattle Agribusiness Partnership Network as a Community Empowerment Institution in Central Java. J. Indonesian Trop. Anim. Agric 44(60):114-22. 
Herianingrum, Sri, Rihfenti Ernayani, Haryo Seto, M. N. H. Rayandono, and M. Q. Fauzy. (2020). "THE IMPACT OF ZAKAT, EDUCATION EXPENDITURE, AND HEALTH EXPENDITURE TOWARDS POVERTY REDUCTION." Systematic Reviews in Pharmacy 11(12):235-39.

Hudaefi, Fahmi Ali, and Neni Heryani. (2019). "The Practice of Local Economic Development and Maqāșid Al-Sharī 'ah." International Journal of Islamic and Middle Eastern Finance and Management.

Ibrahim, Mansor H., and Nafis Alam. (2018). Islamic Economics and Islamic Finance in the World Economy. The World Economy 41(3):668-73.

Iman, Abdul Hamid Mar, and Mohammad Tahir Sabit Haji Mohammad. (2017). "Waqf as a Framework for Entrepreneurship." Humanomics.

Ismail, Nor Hanani Binti. (2018). "Validity Measurement of WAQF Related Research in Scopus Indexed Journals: A Rabbani Approach Analysis." The Journal of Social Sciences Research 2018(Special Issue 6):376-81. doi: 10.32861/jssr.spi6.376.381.

Kamelia, Farha. (2018). "Pengembangan Wakaf Produktif Perspektif Maqashid Syari'ah Al-Syatibi: Studi Di Minimarket Al-Khaibar Universitas Islam Malang."

Kasdi, A. (2016). "Model Pemberdayaan Wakaf Produktif Di Indonesia." ZISWAF: Jurnal Zakat Dan Wakaf 1(1):1-15.

Kashif, Muhammad, Francesco Menoncin, and Iqbal Owadally. (2019). "Optimal Portfolio and Spending Rules for Endowment Funds." Review of Quantitative Finance and Accounting 1-23. Kovacs, Philip E. (2010). The Gates Foundation and the Future of US "public" Schools. Routledge.

Lesmana, Sukma, and Md Harashid Haron. (2019). "MAQASID SHARIAH BASED PERFORMANCE OF ISLAMIC BANKS, ISLAMIC CORPORATE GOVERNANCE, AND CONTINGENCY THEORY: A THEORETICAL FRAMEWORK." International Journal of Accounting 4(24):70-86.

Masyita, Dian, Muhammad Tasrif, and Abdi Suryadinata Telaga. (2005). "A Dynamic Model for Cash Waqf Management as One of the Alternative Instruments for the Poverty Alleviation in Indonesia." Pp. 17-21 in Research paper presented at the 23rd International Conference of the System Dynamics Society, Massachusetts Institute of Technology (MIT), Cambridge, MA, July.

Maulidizen, Ahmad. (2019). "Ibn Khaldun's Economic Thought; The Fair Tax And Its Relevance To The Modern Economy." International Journal of Islamic Business and Economics (IJIBEC) 3(2):73-89.

McChesney, Robert D. (2014). Waqf in Central Asia: Four Hundred Years in the History of a Muslim Shrine, 1480-1889. Vol. 1182. Princeton University Press.

Musa, R. Abdullah, Meddy Harjanto, and Siti Heni. 2015. "Review of Disaster Management Implementation for the Community Safety in the Vicinity of Oil and Gas Field." P. 60005 in AIP Conference Proceedings. Vol. 1658. AIP Publishing LLC.

Nienhaus, Volker. (2010). "Fundamentals of an Islamic Economic System Compared to the Social Market Economy." KAS International Reports 77.

Nor, Amirudin Mohd, Siti Nurulhuda Ibrahim, and Shahreena Daud. (2020). "Recovery Issues on Murabahah Financing in Malaysia." International Journal of Academic Research in Business and Social Science 10(4):295-308.

Nur, Aini. 2018. "Pengembangan Wakaf Produktif Ditinjau Dari Undang-Undang Nomor 41 Tahun 2004 Tentang Wakaf: Studi Di Minimarket Al-Khaibar III UNISMA Malang." 
Rahman, Faried Kurnia, Mohammad Ali Tareq, Rochania Ayu Yunanda, and Akbariah Mahdzir. 2017. "Maqashid Al-Shari'ah-Based Performance Measurement for the Halal Industry." Humanomics.

Rizki, Febriani, Thoyib Armanu, S. Surachman, and R. Rofiaty. 2017. "Study on the Relationship between Islamic Leadership Style, Work Ethics, Job Satisfaction, and Employee Performance." Russian Journal of Agricultural and Socio-Economic Sciences 61(1).

Rofai, Yuli, Umar Burhan, and Multifiah Multifiah. 2016. "The Role of Productive Waqf for Public Welfare (Study Case of Nadzir Foundation in University of Islam Malang)." International Journal of Social and Local Economic Governance 2(2):152-60.

Rokhmiyati, Sri. 2018. "Konsep Manajemen Sumber Daya Manusia Dalam Kelembagaan Islam." Interdisciplinary Journal of Communication 3(2):231-52.

Ruslang, Ruslang, Muslimin Kara, and Abdul Wahab. 2020. "Etika Bisnis E-Commerce Shopee Berdasarkan Maqashid Syariah Dalam Mewujudkan Keberlangsungan Bisnis." Jurnal IImiah Ekonomi Islam 6(3):665-74.

Rusydiana, Aam S., and Irman Firmansyah. 2018. "Efficiency versus Maqashid Sharia Index: An Application on Indonesian Islamic Bank." Shirkah: Journal of Economics and Business 2(2).

Sahlan, Mohd Khairulnizam, Mohd Fauzi Abu-Hussin, and Aminudin Hehsan. 2019. "Market Coopetition: Implications of Religious Identity in Creating Value Added Partnership within Halal Mart Retailers." Journal of Islamic Marketing 10(2):465-75.

Sapuan, Noraina Mazuin, Jegatheesan Rajadurai, Nur Azni Mohd Zeni, and Sahaida Laily Md Hashim. (2018). "Developing a Holistic Business Model for an Efficient Waqf Property in Malaysia." Global Business and Management Research 10(3):445.

Sari, Rina Novi. (2020). "Analisis Akuntabilitas Pengelolaan Dana Wakaf Pada Koperasi Masjid Sabilillah Kota Malang."

Seprillina, Linda, Vika Annisa Qurrata, Bagus Shandy Narmaditya, and Nor Ermawati Binti Hussain. (2020). "The Effectiveness Productive Waqf as a Social Welfare Development Through Community Empowering: A Case in Islamic Hospital Foundation Malang." Review of Integrative Business and Economics Research 9:67-74.

Siddiqui, Nadia, Stephen Gorard, and Beng Huat See. (2016). "Accelerated Reader as a Literacy Catch-up Intervention during Primary to Secondary School Transition Phase." Educational Review 68(2):139-54.

Sobanjo-ter Meulen, Ajoke, Jerker Liljestrand, Joy E. Lawn, Joachim Hombach, Jeffrey Smith, Kim E. Dickson, Flor M. Munoz, Saad B. Omer, B. Adam Williams, and Keith P. Klugman. (2020). "Preparing to Introduce New Maternal Immunizations in Low-and Lower-Middle-Income Countries: A Report from the Bill \& Melinda Gates Foundation Convening 'Allies in Maternal and Newborn Care'; May 3-4, 2018." Vaccine 38(28):4355-61.

Sun, Sunny Li, Mike W. Peng, and Weiqiang Tan. (2017). "Institutional Relatedness behind Product Diversification and International Diversification." Asia Pacific Journal of Management 34(2):339-66.

Utama, Andrew Shandy, and Sandra Dewi. (2020). "COMPARISON OF GOOD CORPORATE GOVERNANCE PRINCIPLES IN CONVENTIONAL BANKS AND ISLAMIC BANKS IN INDONESIA." PROCEEDING IAIN Batusangkar 1(1):57-66. 
Villa, G., B. Adenso-Díaz, and S. Lozano. (2019). "An Analysis of Geographic and Product Diversification in Crop Planning Strategy." Agricultural Systems 174:117-24.

Walker, Judith-Ann. 2016. "Achieving Health SDG 3 in Africa through NGO Capacity Building-Insights from the Gates Foundation Investment in Partnership in Advocacy for Child and Family Health (PACFaH) Project." African Journal of Reproductive Health 20(3):55-61.

Widiastuti, Tika. (2017). "Waqf Productive Efficiency: Evidence from Yayasan Badan Wakaf Sultan Agung, Semarang."

Yazid, Fadhil, Tan Kamello, Yasir Nasution, and Edy Ikhsan. (2020). "Strengthening Sharia Economy Through Halal Industry Development in Indonesia." Pp. 86-89 in International Conference on Law, Governance and Islamic Society (ICOLGIS 2019). Atlantis Press.

Yulianingtyas, Rachmawati, Putri Asmita Wigati, and Anneke Suparwati. (2016). "Analisis Pelaksanaan Manajemen Risiko di Rumah Sakit Islam Sultan Agung Semarang." Jurnal Kesehatan Masyarakat (Undip) 4(4):121-28.

Zakiy, Faris Shalahuddin, Ahmad Muhtadi Ridwan, and Achmad Sani Supriyanto. (2021). "Characteristics of Moslem Families Economy Based on Maqashid Sharia Perspective." Journal of Islamic Economic Laws 4(1). 